\title{
Public Perceptions of Delays in the Release of Police Body-Worn Camera Footage
}

\author{
Christopher L. Bush, PhD
}

Walden University, Minneapolis, Minnesota, United States

(iD https://orcid.org/ 0000-0002-8882-2601

Contact: $\underline{\text { chrisbush1.cb@gmail.com }}$

\section{Abstract}

Delays in the release of police body-worn camera (BWC) video footage have amplified public concerns about police misconduct. People question law enforcement transparency when video from BWCs is not shared with the community in a timely manner. The qualitative case study explores the life experiences of the community and the victims' family related to delays in the release of police BWC footage. Mettler and Sorelle's policy feedback theory was used for the study's theoretical framework. The research questions focus on understanding the lived experiences and perceptions of community relationships with law enforcement around transparency, communication, and information sharing. A qualitative study was used to examine 13 participants to determine which factors influence perceptions of law enforcement by the community and the victim's family when there is delay in the release of BWC video. In addition, I focused on families who have been directly impacted and members of the community who have been indirectly impacted when police BWC video was delayed. Results show that both the community and the victim's family members are requesting changes to community policing initiatives for better community engagement and for building positive relationships, trust, transparency, police legitimacy, and communication. This study presents law enforcement and society with insight on how to improve public perceptions.

Keywords: body worn cameras; police; communication; delays; trust; discrepancies; manipulation; community policing; legitimacy; transparency

Date Submitted: July 12, 2020 | Date Published: September 9, 2020

\section{Recommended Citation}

Bush, C. L. (2020). Public perceptions of delays in the release of police body-worn camera footage. Journal of Social Change, 13, 1-17. https://doi.org/10.5590/JOSC.2020.13.1.01

\section{Introduction}

In the United States, the media has given increased attention to encounters between police officers and the public that have ended badly, sometimes with injury or death (Paulsen, 2016). In many of these cases, video 
footage from an officer's dash and body-worn camera (BWC), as well as from community recording devices, has documented the incidents. There is major concern from the community and victims' families when the video from an officer's BWC is delayed (Mateescu et al., 2016). In recent cases that have garnered national attention, police departments have been slow to comment on the video from BWCs. Farmer (2016) stated that police departments keep information guarded and secured from being leaked by operating in a secretive manner. The delayed video footage, withheld from families and the community, is also not shared uniformly or in a consistent time frame across law enforcement agencies (Thomas, 2016). Thomas stated that this hampers the community/law enforcement relationship nationwide because no consistent time line can be followed.

The introduction of BWC was intended to improve the public's perception of the criminal justice system, specifically regarding law enforcement. The exact opposite has happened and this has further contributed to the black community's determination to express, identify, and validate their views on the injustice, inequalities, and systemic racism directed towards their community. Isom (2016) stated that an "air of injustice" has been present, which clarifies why there is an overwhelming uproar from a disadvantaged community in response to perceived police injustice. The added attention around police BWCs has elevated the community's reasoning that race is a contributing factor to strained relationships between police and the communities they serve. Results of a recent study confirmed that minorities and Whites have different perceptions of policing and the legal systems. These differences are evident and continue to be a problem that must be addressed to understand the impact it has within the legal system (Willis et. al, 2019).

When the police department holds onto the video and does not explain the delay, however, questions surface around transparency. The little trust the community has in the police begins to dissipate, leading to more questions about the transparency of officers (Paulsen, 2014). Police misconduct around BWCs has drawn much attention from victims' families, city officials, and the community. Yet, Berdjis (2016) stated that a minimal amount of research has been conducted on the impact police body cameras have on the community. This research addresses the impact of delayed video on the community and how it further prevents them from building a positive and trusting relationship with the police. When community members learn that policies around BWCs are relaxed or that there is no policy in place until such time as an unforeseen incident happens, they are prone to believe there may be some discrepancies in police stories, as well as the potential for tampering with the BWC video footage (Paulsen, 2014). In conducting this research, I sought to examine the opinions the public has on BWCs and the delayed release of videos.

The inconsistently applied and existing policies in place for law enforcement regarding when to release video create an even more toxic relationship with the community. The public sees no trust, a lack of communication, and no transparency and begins to question the legitimacy of law enforcement's purpose and work. Parry (2017) stated that BWC video delay is becoming a growing problem that is being exposed nationwide, causing community members, law enforcement, and political leaders to step in to make the necessary changes.

To close this gap between police and the communities they are meant to serve, both law enforcement and the community need a collective effort to engage in an active and productive partnership. However, the police must examine their role in this issue and take an honest assessment of themselves and their culture. Police departments should examine how they communicate and interact with their communities and improve their transparency to ensure that their legitimacy and trustworthiness is in good standing with the community. An opportunity exists for police officers and departments to embark on social change; these relationships can be salvaged and better policies can be implemented that work for the greater good for law enforcement and the community.

The purpose of this qualitative study was to explore the perceptions of family members and citizens related to the delayed release of video from police BWC's and how this impacts their ability to trust the police. The study 
may clarify public concerns related to delayed video releases of BWC footage and provide public policy decision-makers with the opportunity to modify or formulate policies on BWC video release to avoid poor relationships with their communities. I collected information on individuals' perceptions and used those developing themes to answer the research questions. Media reports, court cases, and local accounts of incidents involving police BWC video being delayed and not being shared with victim families and communities in a timely manner continue (Mateescu et al., 2016). I explored recent cases and the experiences of individuals who have been impacted by BWC delayed video. I identified other significant contributing factors that affected the community perceptions of law enforcement and what impeded relationships between victim's families, community members, and law enforcement. The following research questions emerged from the literature review:

Central research question: How does the lack of a requirement to immediately release the video to the family members contribute to your distrust of the police?

Subquestion: 1. What do community members believe justifies the delay of video from body-worn cameras?

Subquestion 2. What can policy makers do to improve communication and transparency in your community?

\section{Background}

The intention of adopting BWCs was to establish trust, ensure safety, provide transparency, and inspire officers to improve their conduct with the public, thus improving the relationship between the community and law enforcement (Cao, 2015). Grainer (2016) stated that questions continue to surface regarding the use of BWCs. Communities have requested that law enforcement respond to their demand of adopting BWCs for all police officers. The implementation of BWCs and the policies surrounding them vary widely across departments (Paulsen, 2016). The varying policies have been viewed as inconsistent by the community (Paulsen). Ariel et al. (2014) pointed out that attention paid to law enforcement leadership and personnel has been met with an uproar from families of victims and the community as to why BWC video is delayed. Ariel et al. also said that a variety of research has been conducted on the use of BWC's and news articles have circulated that address the community concerns. Ariel (2016) discussed how body cameras affect how officers manage their contact with citizens. BWC use highlights how officer behavior changes when they know that incidents are recorded, and superiors may review those recordings. The concern that the families and community members have around BWCs' delayed footage and general use supports the need for this study. Furthermore, this study extends scholarship about the lack of policies that are in place to immediately release BWC video to family members and how this increases the public's distrust in the police.

\section{The Literature: Community Policing-Trust, Transparency, Legitimacy, and Policies}

Police departments must begin to examine their overall interactions with the community as they continue to establish policies around community policing (Hemmer, 2017). The prevalence of social media and its ability to quickly capture police misconduct and other negative aspects that can impact police legitimacy provide the community firsthand access to moments that contribute to perceptions of police mistrust. Over the past few years, U.S. police have been in the news for carelessness and irresponsibility with regard to managing their BWC video and their decisions to hold onto video without letting families review it in a timely manner, choices that have impacted communities around the country (Mateescu et al., 2016). When circumstances like this take place, citizens embrace past perceptions of officers that involved police misconduct, discrepancies in their stories, and tampered evidence. For police to narrow the gap between them and the community regarding these perceptions, they must establish trust, starting with communication and transparency with 
their community (Hemmer, 2017; Whitten, 2017). Once police have built better rapport with citizens of their community, they can have conversations to rectify past and current problems. Researchers such as Hemmer, Lee (2016), and Whitten contend that, in this way, police departments can reduce any future barriers.

Therefore, after a plan has been put in place to start these conversations, both the community and police must embrace a collective effort. This will ultimately improve the community's trust in the police and ensure that police are accountable and transparent with sharing needed information. More communication may minimize any skepticism the community may form by allowing members to be engaged in conversation early on. To achieve such a goal, the police will need to provide education and training on what can be shared and what information needs to be secured so the community has better understanding (Escutia, 2016). Police can review and discuss with the community current policies, which the community may question, and police can take part in feedback sessions to help members of law enforcement go back and examine what can be changed or done differently. I reviewed key literature concepts related to the study topic's theoretical framework. Emerging relevant topics in the literature review included the history, purpose, and use of BWCs; policies for BWCs; police transparency and legitimacy; and community policing. Several theories could have been used as lenses for this study. I chose the policy feedback theory (PFT) (Mettler \& Sorelle, 2014), which focuses on communication and was the most fitting to answer the research questions .

\section{Policy Feedback Theory-Solution to Implementing Policies with the Community}

I used a framework centered around communication, specifically, the PFT, which emerged in the 1980 . (Mettler \& SoRelle, 2014). The PFT served as the lens to examine the problem and support data collection and analysis. PFT encompasses the determination of a policy's legitimacy (i.e., whether it is appropriate or inappropriate), according to Mettler and Sorelle. The PFT is grounded in historical institutionalism. Developed in the 1970s, historical institutionalism is an approach to understanding the effects of policies by considering their context, providing a larger framework for understanding the policy's origins and outcomes (Mettler \& SoRelle). Mettler \& SoRelle explored historical institutionalism over the past 5 years, a time in which focus has been on political factors, giving them clear direction to emphasize how PFT can be a resource for reviewing policies. Mettler and SoRelle collaborated to show how PFT can be incorporated to explore outcomes of policies once implemented.

Building on their work, I show how PFT can engage the community to be assets in terms of being individuals who can review old policies that are simply not working or driving a wedge between community and police. Overall, this framework allowed the community, local city officials, and government to examine how policies influence attitudes and behaviors and how working collaboratively can be a success for all involved. I used PFT to guide this study, addressing the influence of BWC video policies that affect the community and victim's families to answer the research questions. The overall goal explored PFT outcomes from past and present circumstances that were being questioned and determined how the negative feedback about the policy influenced future policy decisions. Giving communities the opportunity to have a seat at the table to make decisions on old and newly developed polices provided clarity that some positive attributes can diffuse over time to neighboring counties, cities, states, and possibly globally, where social change can take place.

\section{Method}

The purpose of this study was to investigate how law enforcement officers' use of BWC video impacts the community and to learn what perceptions community members have about police when controversial BWC video is delayed. I examined the relationship that victims' families and citizens of the community have with police after they have lived through weeks without BWC footage release. I obtained information about the victims' families and the community perceptions about police communication, transparency, and legitimacy 
around BWC policies. After providing an overview of steps taken to address the research questions, I describe the population and the sample of participants used to collect data as well as the procedures for sampling, recruitment, data collection, and data analysis. I used a qualitative approach, focusing on families who have been directly impacted and members of the community who have been indirectly impacted when police BWC video is delayed. Finally, I reviewed news articles to compare to participants' feedback from the interviews. I compared these to demonstrate how, across the country, family and the community feedback aligned with the interview questions presented to the 13 participants.

Participants were selected based on a purposive sampling for this research that targeted a diverse population throughout the Topeka, Kansas, community. All of the individuals shared the experience of being impacted about the news of BWC video being delayed. The targeted population consisted of male and female participants who identify as white, black, Hispanic, or other. Topeka is in Shawnee County, which in 2017 had a population of 178,187 . This research identified two family members from Topeka, Kansas, who have been directly impacted by police BWC delayed video to help provide a more in-depth conversation of how their lives have been impacted and who have shared their perspectives from a personal experience through the tragic deaths of their loved ones. The two family members selected for this study were directly targeted as they have made themselves available for contact through social media. The other 11 participants were recruited from local church congregations and from Topeka and surrounding communities.

The focus of this research was not to collect data based on race responses, but to filter through the community by identifying local churches located regionally where the congregations depict diverse backgrounds who could participate and provide feedback around BWC delayed video. This research aimed to learn, understand, and become knowledgeable about a real-world phenomenon affecting the community and impacting its trust in police when BWC video is delayed. Ravitch and Carl (2016) stated that sampling is the decision the researcher makes in relation to knowing ahead of time from where and whom the data will be collected to answer the questions related to the gap in the research.

A purposeful sampling was used to select the participants for this study. The sample size for this research was scheduled to be 22 participants. The participants were selected through the 10 identified churches that have been active in the Topeka community. I selected a minimum number as opposed to large number from each congregation with the focus being one female and one male from each. The total number of members from churches was scheduled to be 20 participants; 10 males and 10 females. The additional two participants are families of victims from police excessive force incidents involving BWC video delays. They were chosen by making themselves available for contact regarding the incident that took place with their loved one. There were other cases in Kansas, but no information from the families has been shared with the public for contact. The twenty members from church congregations and the two family members that were originally chosen totaled 22 participants for a sample size for this research. This research was better suited for typical case sampling to study how BWCs affects the victims' families and the community. Typical case sampling is useful when a researcher wants to study a phenomenon or trend as it relates to what are considered "typical" or "average" members of the affected population. I selected identified families of victims and the community who were the most knowledgeable about their perceptions regarding body worn camera (BWC) delayed video release and could provide firsthand experiences to help learn more about the research topic (Rudestam \& Newton, 2015).

I chose the qualitative approach because it allowed me to obtain the personal perceptions of individuals who are impacted by delayed video releases of BWC footage from their lived experiences. The design of the research was imperative to this study to ensure alignment with the foundation that the research rested upon and the framework that held it together. Also, the focal point of this study was positioned around the discovery and understanding of the impact that police BWCs have had on individuals since their inception around 2014 and 2015. More specifically, I focused on two topics that have not been studied according to my 
review of the literature: the impact of BWC delayed video releases on the families of victims and members of the community and how it affects their perceptions of police departments from their lived experiences.

The qualitative approach allowed me to elicit an in-depth perspective on the experiences of the participants around police BWCs. Rubin and Rubin (2016) explained that the data collection methodology used within a qualitative study should allow participants to share their experiences. For this reason, I focused on multiple approaches that involved conducting telephone and face-to-face interviews and emailing the questions. Posing semistructured/open-ended questions allowed me to capture in-depth data to capitalize on emerging themes. The main constructs that I focused on during the interviews included the impact of BWCs when release of the video is delayed and how BWC policies affect community perceptions.

Along with collecting families and community perceptions of the phenomenon, I examined past and current events. I turned my focus on document analysis (Rubin \& Rubin, 2012) involving examining documents that include newspaper articles, speeches, transcripts, and internet posts. Information on each event was collected through multiple sources to build a full description of the events (Rudestam \& Newton, 2015). I used these publicly available documents to develop case themes and patterns of inconsistent approaches handled by the police around BWC video release. This study described the events and various incidents around BWC delayed video releases and polices that were in place or were lacking to better inform readers through family and community perceptions from their experiences regarding the impact BWC delayed video has on them, and through looking at past and current cases that are the most appropriate for this research. Qualitative data collection research includes: Interviews with audio/and or video tape; direct, non-participant observation; participant observation; field notes, journals, and logs. Rudestam and Newton (2015) described data collection and logistics being subsumed under procedures. I selected events that have been in the news and data was collected from mass media outlets: newspaper articles, online news articles, broadcast news reports (television and radio), photos, and online news videos; police reports from the respective departments involved in each case; social media messages from activists and concerned parties; citizen video taken by bystanders and witnesses to the events; as well as police surveillance footage including body cameras and police car dashboard cameras.

This research provided detailed notes from each interview to further analyze major themes developing during the interviews. Recording the interviews ensured that I captured verbatim conversations for ease of transcription. At the conclusion of gathering the participants' feedback each research participant was provided a copy of the interview transcription via email to ensure it is an accurate interpretation of the intended purpose of the interview. The open-ended questions helped obtain information regarding participant experiences to create an insightful, informal, interactive environment that directly focused on the participants' experience as they lived it or were impacted by the event (Rubin \& Rubin, 2012). Some participants results that pertains to questions around access to review the footage, and participants perception about law enforcement:

P3: I believe that officers hold on to video because they do not want other to see entirety of video. I believe that they can be editing the video, they're covering their butts, trying to get attorneys lined up for any misconduct that might be there.

P5: If you have nothing to hide release the video. If you are being up front you will show good or bad... not willing to do so I think it is bad.... But, I think that the risk that they take in not releasing video immediately impacts everyone. Gives a perception that if the police are holding onto it without releasing the video, that you start to think that it's worse than what we already know, and some changes are being made to the video.

P7: If video is not released then it seems like they are hiding something, keeping something from the family pertinent information. I would lose trust if something was being withheld from me to review 
immediately. As a family member and as a citizen, I would think things are being deleted and edited.

P9: If there is a delayed time to release the video, I assume this leave time for stuff to be tempered with.

P11: So some editing could take place if it is in the hands of officers too long without the family being seeing it.

P1: My dealings with the law enforcement changed my perception about them. I cannot stomach to even look at the DA, the Chief, City Manager or any of them.

P2: Until this happened in my back yard and then seeing it happening worldwide, my perception has changed.

P7: As a citizen my perception is, not all Topeka cops are bad cops.... all it takes is one bad cop to give a bad wrap. The incident with the White case left a bad impression on many people of the community especially to the victim family.

Participants shared in-depth response about a neutral person being present with the family to review the video:

P1: I do not believe there is a neutral person. I believe the DA, the Governor, the Mayor, the City and the Police department are all in cahoots together and none of them could be neutral. Possibly the FBI should come in and take all the evidence and not leave it with the same police department that is being reviewed."

P2(f): Family should have a private viewing, long as it is not anyone associated with police department and community members could be chosen by officers identified who they feel more comfortable with, so they shouldn't have a say so in identifying a neutral person.... I do believe a family member must be present... maybe with a pastor or legislator could serve as being neutral.

P3: There should be a citizen panel a single person would become bias. Should be on a rotating basis like a jury duty. There is nothing that justifies the delay of video release.... maybe to the public but not even to us either.

P4: Should always be a neutral person.... not like they will be called everyday (like an appointed person for a short time... should not be law enforcement officer who was engaged, or city managers cannot be neutral not even another police department.... A neutral person could be advisory group and each of them should go through some type of training, understand implicit bias.

P5: Court system may be one alternative to identify a neutral person.... will be difficult to establish in the beginning... neutral to who... not sure who fits in.... ACLU may be a consideration... someone who advocates.

P6: Neutral person should be someone that is not law enforcement that has no opinion or one sided... maybe a sitting judge. The family should have say who the neutral person is.

P8 "Yes...having a person(s) or citizen review would be idea to have as neutral person...this person or persons can be no way connected to the police (mayor, city council, or any other police departments)."

The following responses shared a similar response around police trustworthiness, what strategies can be implemented to ensure there is efforts to build relationships to close the gap revealed responses that supported some of the efforts and some that questioned the efforts: 
P1(f): Believe it or not, I hoped that they would do the right thing. Now, I know that they are anything but transparent, legitimate and trustworthy. They are full of criminals that wear badges that allow them to do things that would send you or I to jail. It is so much deeper than just law enforcement, it goes all the way up. I guess my perception to answer your question is that they are corrupt, phony and dishonest.

P2(f): I don't trust them, I don't believe their transparent at all they are not legitimate... I been in Topeka 53 years, I been through all the changes... nothing really changes.... There are just good old boys. The officer who shot the Llamas brothers off duty is now a detective. How does that happen? Officer who killed White killed a dog, killed a person in a car accident still employed.

P3: Chief is trying...they need to get rid of the old corrupt officers they make it hard on the new younger officers who is trying.... Transparency is squat. There is none. There's no transparency. Officers that are still there, they were trained under those corrupt from top to bottom. You've got some in the middle that are in their thirties that are trying and ok, it's about 50, 50. I do believe that the younger officers are trying to make a difference in their community.

P4: Much better than the past. The chief is trying... doesn't want to be the legacy of the last chief... because of the incident that had happened with 102 White.... no one should blame him under the past leadership... not too much to be transparency with not much incident.

P5: Honestly, I think they are trying to do better since work is being done going into the community.... the chief is starting to be more engaged... in the beginning much more was being done shortly after the White shooting, seemed to may have slowed down a little... not much change as of lately.

P9: More need to be done.... they are attempting to do more, but not enough is being done. Not sure how long this will last.

P11: Having been a person who was on the other side that have been arrested, I do see some better intervention, but just when certain things come up is where they put themselves at question when the community go back to not trusting their whole aspect of work.

I provided interview questions to all participants a week ahead of time to give them time to prepare for the questions. The choice to conduct interviews for this study was in regard to the growing concern around BWC video release to gain a better understanding of the community experience from a perspective of faith-based participants who will not be biased regarding race, behaviors of the community impacted by delay of BWC video after learning that policies are not followed or simply not in place, and relationships of the study participants.

Because the data collection for this research, with the moderate sample, could be time consuming, I felt it imperative to mange time appropriately and effectively for self and participants. I conducted a general pilot test for the purpose of testing the questions and looking at time management regarding the time spent with the participants. I selected two colleagues to participate to determine if the time is reasonable along with evaluating how the selected pilot participants answer the questions. In addition, the primary reason for the pilot test was for the researcher to check for consistency of questions assuring that the responses are consistent. Finally, I coded the responses to see how themes emerged from the responses of the two selected pilot participants.

\section{Results}

The results from this study provides insight to participant's perceptions that involve police body-worn camera 
delayed video release. The research describes that failed communication concerning when BWC video will be released hampers the relationships of the community and family members to establish trust from the police. Individuals impacted by events where there is a delay of video release began to speculate if there were any discrepancies in law enforcement communication, how true they to their word, and the legitimacy of the work they are doing.

Ten interview questions were used for this research to help address the central research question and two subquestions emerged from the literature review. Three of the interview questions fall under the central research question, "how does the lack of a requirement to immediately release the video to the family members contribute to your distrust of the police?" Three other interview questions that differ from what fell under the central research question fall under the sub-question \#1: What do community members believe justifies the delay of video from body worn cameras? The remaining 4 interview questions fit under sub-question \#2, What can policymakers do to improve communication and transparency in your community?

A total of 11 themes emerged from the interview responses. The predominant emerging themes were:

1. Video that is held back immediately alerts to something being hidden.

2. There is no justification to delay video.

3. Only the family member should make the decision to delay video.

4. Officers remained employed after their unethical acts.

5. Policies seem to fit the department and do not include the community.

The overall results collected from the families and community participants' perceptions impacted by police body worn camera delayed footage and policies aligned with the secondary data news articles, where the predominant themes emerged. I analyzed three specific incidents that recently gained national attention around police BWC's delayed video release: the murders of LaQuan McDonald in Chicago, Sylville Smith in Milwaukee, and Dominique White in Topeka.

The predominant themes that emerged from the interviews and the articles are listed below.

\section{Overall results for Central Research Question}

Individuals expressed their feelings associated with the delay of the video and all expressed having the same feeling they had to go through during the waiting of the video and how the feeling continues even when the video was released.

\section{Results for Subquestion 1}

All participants believed that the family should have a neutral person but only with the family having some input who the neutral person is. The participants also asked how do you define neutral?

\section{Results for Subquestion 2}

All the participants agreed that some form of interaction should include emerging community leaders other than community leaders who are always called upon to take part in discussions around policies and all other community and police matters.

The tables below provide a visual of the codes and themes that emerged from the interviews, and news articles. 


\section{Summary of the Main Results From the Research Question}

The families and the general community, along with the secondary data, all expressed the same feeling and perceptions around the delay of police BWC footage and lack of polices. The families who were directly impacted that were interviewed and family's stories in the news articles along with the community all agreed that video should not be delayed. Furthermore, they all agreed that the video should at least be shared with the family immediately. However, the participants stated that they respect the work and understand that the investigation must take its course, but felt that sometime this prolongs the delay intentionally, which further erodes their trust in police. The other major correlation from the three research questions demonstrated that there is concern around current polices in place that do not address issues that emerge and the lack of policies that do not exist until an incident occurs. Also, there is concern that policies not being appropriately implemented impedes police and community relationships.

Data saturation set in when I got to the ninth participant interview and stopped the data collection at 13 participants, whereas all the data was recorded as the same feedback from the participants and from the data collected from the three articles. Table 1 includes coding words and themes from the 13 interviews. In addition, themes that emerged from the articles that aligned with the themes from the interviews are marked with a check mark under the column labeled Article Themes along with the articles used to triangulate the data with interviews.

Table 1: Alignment of Interview Codes and Themes to News Articles Themes

\begin{tabular}{llc}
\hline Interview code & Interview theme & $\begin{array}{c}\text { Article } \\
\text { theme }\end{array}$ \\
\hline Trust & $\begin{array}{l}\text { Video that is held back immediately alerts to something is } \\
\text { being hidden. }\end{array}$ & \\
Transparency & Tampering, reediting or modified video. & $\checkmark$ \\
Communication & There is no justification for video being delayed. \\
Community & Video should be shared even during the ongoing investigation. & $\checkmark$ \\
Delay & A neutral person should be one who has implicit bias \\
& training. & $\checkmark$ \\
Body Worn Cameras & Only the family member should make the decision to delay & \\
Tampered & video. & $\checkmark$ \\
Manipulate & Progress is being made here in Topeka. \\
Hide & Officers remained employed after their unethical acts. \\
Misinformation & Communication is a need to implement strategies. & $\checkmark$ \\
& Policies seem to fit the department and does not include the & \\
Belong/Member & community. & \\
& Officers should not only have to live in the community but & \\
& come from the community. & $\checkmark$ \\
\hline
\end{tabular}

Table 2 lists the articles that provided data that I used to triangulate with the interviews. The articles are news stories that focus on Laquan McDonald's 2015 shooting, Sylville Smith's 2015 shooting, and Dominque White's delayed video release. Several articles were reviewed where I pulled data that reference the family and community comments around the delay of video from the police body worn camera. 
Table 2: News Articles on Delayed Video Release

\section{News Articles}

\section{LaQuan McDonald}

City delays release of police shooting video despite 90-day policy. (Hinkel, 2017)

Change Is Needed: Family of Laquan McDonald Speaks Publicly for First Time Since Video Release. (Marin, 2015)

"The Buck Stops Here in Chicago": Laquan McDonald Supporters, Family Gather to Discuss Historic Jason Van Dyke Verdict. (NBC Chicago, 2015)

Laquan McDonald's family does not want police shooting video released. (Hall, 2015)

\section{Sylville Smith}

Video release of Milwaukee Police shooting delayed. (Luthern, 2016)

Why Police Departments Don't Always Release Body Cam Footage. (Sandburn, 2016)

Speculation about Milwaukee shooting video mounts. (Luthern, 2016)

Your Right to Know: Public's trust was abused over police videos.

(Lueders, 2017)

\section{Dominique White}

Family wants answers a week after police shot and killed Topeka man.

(Koenen, 2017)

Video shows aftermath of deadly Topeka police shooting as family continues to search for answers. (Schladebeck, 2017)

Compromise Could Free Cop Cam Videos in Kansas More Quickly. (Koranda, 2018)

Police should release video. 2017, Nov. 21 ("Police Should Release Video," 2017))

Release of police body camera recordings varies across Kansas. (Moore 2018)

Release the body cams of the officers who shot and killed Dominique White. (Joyce, 2017)

Protesters call for more transparency in LPD investigation of Topeka shooting. (Bernard, 2017)

Death Certificate: Dominque White died as a result of gunshot wounds to his back. (Moore, 2017)

Table 3 highlights the codes and themes from the articles compared with the previous themes and codes from the participants' responses. Out of the 11 participant themes, article themes aligned with eight of them. Some of the same code words that emerged in the articles matched participants' comments. They are marked with 
Bush, 2020

three asterisk marks $\left(^{* * *}\right)$. Table 3 depicts the overall results from participants and secondary data.

Table 3: Codes/Article Themes and Themes from Interviews of Participants

\begin{tabular}{|c|c|c|}
\hline Codes & Article themes & Participant themes \\
\hline $\begin{array}{l}\text { No answers/unanswered- } \\
\text { Communication**** }\end{array}$ & $\begin{array}{l}\text { Will not rest until they get } \\
\text { answers/looking for answers }\end{array}$ & $\begin{array}{l}\text { \#1 Video that is held back } \\
\text { immediately alerts to } \\
\text { something being hidden }\end{array}$ \\
\hline \multirow{12}{*}{$\begin{array}{l}\text { Footage } \\
\text { Transparency/not knowing *** } \\
\text { requested info / communication } \\
* * * \\
\text { Not knowing/delay } * * \\
\text { Not revealing } \\
\text { Police \& community relationships } \\
\text { Hiding/misinformation } * * *\end{array}$} & Make the video public & \multirow{3}{*}{$\begin{array}{l}\text { \#2 People are left feeling } \\
\text { suspicious that there is } \\
\text { tampering, reediting or } \\
\text { modifications to the video }\end{array}$} \\
\hline & Unrivaled due to the transparency & \\
\hline & Family left pondering for & \\
\hline & \multirow{2}{*}{$\begin{array}{l}\text { Minimal details released by } \\
\text { authorities }\end{array}$} & $\begin{array}{l}\text { \#3 There is no justification } \\
\text { where video should be delayed }\end{array}$ \\
\hline & & \# A Video should be shared \\
\hline & \multirow{7}{*}{$\begin{array}{l}\text { The system is deeply flawed } \\
\text { Lack of transparency-no } \\
\text { engagement in the community } \\
\text { What is stopping you from releasing } \\
\text { the video }\end{array}$} & even during the ongoing \\
\hline & & investigation \\
\hline & & \#6 Only the family member \\
\hline & & $\begin{array}{l}\text { should make the decision to } \\
\text { delay video }\end{array}$ \\
\hline & & $\begin{array}{l}\text { \#8 Officers remained } \\
\text { employed after their unethical } \\
\text { acts }\end{array}$ \\
\hline & & $\begin{array}{l}\text { \#9 Communication is a need } \\
\text { to implement strategies }\end{array}$ \\
\hline & & $\begin{array}{l}\text { \#10 Policies seem to fit the } \\
\text { department and does not } \\
\text { include the community }\end{array}$ \\
\hline
\end{tabular}

\section{Discussion}

In conducting this phenomenological qualitative research study, I sought to close the gap in scholarly literature on the impact of delayed release of BWC video as perceived by community and family members. Discussion of the findings in relation to the theoretical framework, the limitations of the study, future research areas, and a summary are included. Police BWCs have become a popular topic ever since the Ferguson incident in 2014 involving the officer involved shooting and killing of an 18-year-old African American, Michael Brown (Farmer, 2015). BWCs have brought attention to law enforcement trustworthiness, honesty, and legitimacy (Ariel, et al, 2014). In addition, their use has shed a light on how community members view law enforcement.

This research provides insight on the opportunities stakeholders might be able to exploit to build better policies and increase community and police engagement. Such communication may lead to better relationships. The PFT (Mettler \& Sorelle, 2014) allowed me to demonstrate how communication can be established between individuals, business leaders, and organizational leaders. However, the primary purpose of using the theoretical framework was to gain insight on the relationship between community and law enforcement can be better when communication is the leading factor. The PFT tests the appropriateness of 
policies and the effects of lack of communication on victims' family members and the community.

The study showed that both the community and the victim's family members are requesting changes to community policing initiatives for better community engagement and for building positive relationships, trust, transparency, police legitimacy, and communication. The feedback from the participants confirmed the need for better policies around communication and the release of BWC in order to stop video from being delayed. Participants agreed that being at the table at the time policies are being reviewed or developed around BWC video and other related polices that impact the community makes a difference when policies are enforced. Parry (2017) stated that BWC's video delay is becoming a growing problem that is being exposed nationwide, causing the community, and some leadership, to step in to make the necessary changes. Duck (2017) implied that policy-makers could learn from the community experiences and perspectives if they allow individuals to engage in conversation. This finding supports the underpinnings, of the Policy Feedback Theory, which provides a framework to see through the lens of integrating community, law enforcement, and all other disciplines to work collectively through communication.

\section{Implications for Social Change}

This research contributes to positive social change that can impact relationships and lead to creating or updating policies relevant to the PFT in regards to assisting in creating a greater community structure and engagement between law enforcement and the citizens. The interview responses collectively addressed the community request for change around police officer's trustworthiness and transparency that expose the legitimacy of their work that can be a possible start to closing the gap in the relationships with the community. The participants believe initiatives for policy engagement could be done right now and moving forward that can embark on social change that could positively impact the victims' families and the community.

P7: So I think TPD is on the right track now. Could they do more? Of course, they can, but something is always better than nothing. Right. So, I applaud them for what they have already started.

P8: Better...but more need to be done...just not enough.

P9: More need to be done...they are attempting to do more but not enough is being done...not sure how long this will last.

The data from the articles analyzed also revealed the same feedback on positive social change the participants had suggested. Their responses reflected a simple request to just have a better line of communication in place that is inclusive of everyone. Overall, this study's implications for positive social change be implemented in Topeka but also be applied throughout Kansas and across state borders with many entities at the table. This phenomenon engages multiple people to be at the table from all ethnical backgrounds and disciplines.

\section{Recommendations}

This study offers a myriad of possible future recommendations that can extend research for similar topics that I have explored and researched on police BWC's delayed video release. Further studies that can be employed around police body worn camera policies and communication are: how does the release of police body worn camera video of youth under 18 that are apprehended affect parents? When officers immediately review BWC video, how is the officer's written report influences? Future research on police and community communication around policy change from victim's perspective could reveal more positive social change that can also increase police and community relationships.

Communication, policy change and community policing are only a few contributions that have been 
earmarked for future research around the phenomenon of police body worn. Several other factors from the results produced some possible topics for future research that came from several of the code words and themes identified, including transparency, trustworthiness, hiding, and more. One major area that the research did not reveal was the impact children endure. Children are being recorded and parents are not being notified that there is footage of their underage youth stored in a database. Future research can also explore police legitimacy in respect to the ethics of their work concerning whether officers should have an opportunity to write/rewrite their report after reviewing BWC video.

Lastly, a future study for this specific topic could applying a quantitive approach, looking at how it takes a community to become unraveled, irritated, and lose more trust (days, hours, etc) when video is not released. BWCs continue to gain national attention whether from lack of policies or lack of communication on their use.

\section{Conclusion}

The lack of communication contributes to the distrust that families and the community have towards law enforcement that drives a gap in community police relationships that is triggered by police transparency, their trust, and the legitimacy of their work. Furthermore, this study utilized the PFT to show how communication can be implemented and started with law enforcement and the community. This process that has been established can restore past and current relationships to build effective strategies that engage everyone to review polices, discuss new polices, and explore new ideas that can be diffused and later adopted. This could decrease community uproar when events occur where policies must be reinforced. The research was developed with to illuminate the feelings and concerns that immediate family and community members had around policies that are inconsistent around the country where each law enforcement agency implemented their own policy to when video from BWC will be released. Through triangulation from the participant responses and news articles it was discovered that the families who were directly impacted and the community whom was indirectly impacted along with the comments from the articles (family members and community supports) all believed the following: there should be no delay of video from police body worn cameras, family should have a say in the release, and polices should be uniform and consistent among law enforcement in the country. The findings confirm the perceptions the families and communities have towards police officers when BWC footage is delayed. 


\section{References}

Ariel, B., Farrar, W. A., \& Sutherland, A. (2014). The effect of police body-worn cameras on use of force and citizens' complaints against the police: A randomized controlled trial. Journal of Quantitative Criminology, 31(3), 509-535. doi:10.1007/s10940-014-9236-3

Berdjis, N. (2016) A descriptive study on police body cameras and civil liability cases [Master's thesis]. University of Colorado.

https://mountainscholar.org/bitstream/handle/10976/166652/Berdjis uccs 0892N 10224.pdf?seq uence $=1$

Bernard, K. (2017, November 14). Protesters call for more transparency in LPD investigation of Topeka shooting. The University Daily Kansan. http://www.kansan.com/news/protesters-call-for-moretransparency-in-lpdinvestigation-of-topeka/article 75cccc9a-c958-11e7-884c-677e2054eoc7.html

Cao, L. (2015). Differentiating confidence in the police, trust in the police, and satisfaction with the police. Policing: An International Journal of Police Strategies \& Management, 38(2), 239-249.

Duck, W. (2017) The Complex dynamics of trust and legitimacy: Understanding interactions between the police and poor black neighborhood residents. Annals of the American Academy of Political \& Social Science, v. 673, n. 1, p. 132-149.

Escutia, X. (2016). Body-worn cameras, procedural justice, and police legitimacy [Dissertation]. California State University, Long Beach. https://pqdtopen.proquest.com/pubnum/10196208.html

Farmer, A. K. (2016). Copwatchers: Citizen journalism and the changing police-community dynamic [Dissertation]. University of Delaware. https://udspace.udel.edu/bitstream/handle/19716/19904/2016_FarmerAshley PhD.pdf?sequence= 1\&isAllowed $=\mathrm{y}$.

Hall, G. (2015, November 20) Laquan McDonald's family does not want police shooting video released. WGNT. https://wgntv.com/news/laquan-mcdonalds-family-does-not-want-police-shooting-videoreleased/

Hemmer, J. W. (2017). Exploring police beliefs in community-oriented policing and community trust: A multiple case study (Dissertation). ProQuest Dissertations \& Theses Global. (1965399982).

Hinkel, D. (2017, April 10). City delays release of police shooting video despite 90-day policy. Chicago Tribune. https://www.chicagotribune.com/news/breaking/ct-chicago-police-shooting-video-policymet-20170410-story.html

Joyce, A. (2017, September 28) Release the body cams of the officers who shot and killed 131 Dominique White [Web log post]. Change.org.

Isom, D. (2016). An air of injustice? An integrated approach to understanding the link between police injustices and neighborhood rates of violence. Journal of Ethnicity in Criminal Justice, 14(4), 371392. https://doi.org/10.1080/15377938.2016.1209143

Koenen, G. (2017, October 5) Family wants answers a week after police shot and killed Topeka man. KSNT News [Topeka, KS].

Koranda, S. (2018, February 21) Compromise could free cop cam videos in Kansas more quickly. https://www.kcur.org/government/2018-02-21/compromise-could-free-cop-cam-videos-in-kansasmore-quickly

Lee, T. (2016). Tennessee citizens police academies: Program and participant characteristics. American Journal of Criminal Justice: AJCJ, 41(2), 132 236-254. 
Lueders, B (2017, January 3) Your Right to Know: Public's trust was abused over police videos. Wisconsin Watch. https://www.wisconsinwatch.org/2017/01/your-right-to-know-publics-trust-was-abusedover-police-videos/

Luthern, A (2016, August 18) Speculation about Milwaukee shooting video mounts. Milwaukee Journal Sentinel. https://www.jsonline.com/story/news/nation-now/2016/08/18/milwaukee-policeshooting-video-speculation/88938532/

Luthern, A. (2016, August 23) Video release of Milwaukee Police shooting delayed. Tribune News Service. https://www.governing.com/topics/public-justice-safety/tns-milwaukee-police-shooting-bodycamera-footage.html

Marin, C. (2015, December 11) Change is needed: Family of Laquan McDonald speaks publicly for the first time since video release. NBC Chicago. www.nbcchicago.com/news/local/Family-of-LaquanMcDonald-to-SpeakPublicly-for-First-Time-Since-Mayor-Emanuels-Apology-361559221.html

Mateescu, A., Rosenblat, A., \& Boyd, D. (2016). Dreams of accountably, guaranteed surveillance: The promises and costs of body-worn cameras. Surveillance \& Society, 14(1), 122-27. doi: $10.2139 /$ ssrn.2569481

Mettler, S., \& Sorelle, M. (2014). Policy feedback theory. In P. A. Sabatier \& C. M. Weible (Eds.), Theories of the policy process. (3rd ed., pp. 151-181). Westview Press.

Moore, K. (2017, November 3) Death certificate: Dominque White died as a result of gunshot wounds to his back. Topeka Capital Journal. https://www.cjonline.com/news/homicides/local/2017-11-03/deathcertificate-dominique-white-died-result-gunshot-wounds-his

Moore, K. (2018, January 2). Release of police body camera recordings varies across KS. Topeka Capital Journal. https://www.cjonline.com/news/local/2018-01-02/release-police-body-camera-recordingsvaries-across-kansas

NBC Chicago. (2015, October 5). "The buck stops here in Chicago": Laquan McDonald supporters, family gather to discuss historic Jason Van Dyke Verdict. www.nbcchicago.com/news/local/laquanmcdonald-family-reacts-to-jason-vandyke-verdict-495315041.html

Parry (2017). Watching the watchmen: How videos of police-citizen encounters influence individuals' perceptions of the police. (Dissertations). ProQuest Dissertations Publishing. (UMI No. 10276288).

Paulsen, D. (2016). Public opinion about police use of body-worn cameras. (Dissertation). ProQuest Dissertations \& Theses Global. (UMI No. 10163614).

Police should release video [Editorial]. (2017, November 16). Lawrence Journal World. https://www2.ljworld.com/news/2017/nov/16/editorial-police-should-release-video/

Ravitich, M. S., \& Carl, M.D. (2015). Qualitative research. Building the Conceptual, Theoretical and Methodological. Sage Publishing

Rubin, R. (2012). Qualitative Interviewing. The Art of Hearing Data. (3rd. ed.) Sage Publishing.

Rudestam, E. K., \& Newton, R. R. (2015). Surviving your dissertation. A comprehensive guide to content and process. Sage Publishing. (4th edition).

Sandburn, J. (2016, August 17) Why police departments don't always release body cam footage. Time. Retrieved from https://time.com/4453310/milwaukee-policesylville-smith-body-cams/

Schladebeck, J. (2017, October 4) Video shows aftermath of deadly Topeka police shooting as family continues to search for answers. New York Daily News. https://www.nydailynews.com/news/national/videoshows-aftermath-deadly-topeka-police-shooting-article-1.3541443 
Thomas, E. (2017). The privacy case for body cameras: The need for a privacy-centric approach to body camera policymaking. Columbia Journal of Law and Social Problems, 5O(2), 191-228.

Whitten, E. L. (2017). A case study of the effects the current community policing models have on rural police leaders in the south-central United States (Dissertation). ProQuest Dissertations \& Theses Global. (1874980994).

Willis Esqueda, C., Schlosser, M. J., Delgado, R. H., \& Orozco Garcia, D. (2019). Perceptions of the criminal justice system by minority and majority group university students: The role of ethnic identity. Journal of Ethnicity in Criminal Justice, 17(1), 1-15. https://doi.org/10.1080/15377938.2018.1512918

The Journal of Social Change, sponsored by Walden University, welcomes manuscripts focusing on interdisciplinary research in social change that improves the human condition and moves people, groups, organizations, cultures, and society toward a more positive future. 